\title{
A potential anti-tumor drug: Co-crystal 5-fluorouracil-nicotinamide
}

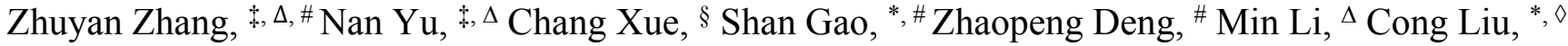
John Castellot, ${ }^{*}, \dagger$ Siying Han ${ }^{*}, \diamond$

${ }^{\Delta}$ Pharmaceutical Experiment Teaching Center, College of Pharmacy, Harbin Medical University, Harbin 150081, China

\#Key Laboratory of Functional Inorganic Material Chemistry, Ministry of Education, School of Chemistry and Materials Science, Heilongjiang University, Harbin 150080, China

§Tufts University Sackler School of Biomedical Sciences, Boston MA USA 02111

'Department of Integrative Physiology and Pathobiology, Tufts University School of Medicine, Boston MA USA 02111

${ }^{`}$ Department of Pharmaceutical Analysis and Analytical Chemistry, College of Pharmacy, Harbin Medical University, Harbin 150081, China 


\section{Table of Contents}

1. Materials and methods

2. General solution method for the synthesis of 5-fluorouracil-nicotinamide (5-FU-NCM) co-crystal

3. Grinding method for the synthesis of 5-fluorouracil-nicotinamide (5-FU-NCM) co-crystal

4. X-ray Crystallographic Measurements

5. IR spectroscopy

6. TG analysis

7. Luminescent Properties

8. Determination of solubility and oil - water partition coefficient

9. Cell inhibitory assay

10. Determination of cell cycle Determination of cell cycle

11. Assessment of Apoptosis by Annexin V-FITC/PI Staining

12. In vivo anti-tumor activity

13. Pharmacokinetics in vivo

14. References 


\section{Materials and methods}

All chemicals and solvents were of A.R. grade and HPLC grade and used without further purification. RPMI1640, fetal bovine serum (FBS), and other cell culture reagents were purchased from Gibco. The Annexin V-FITC/PI kit and RNase A and propidium iodide (PI) were purchased from Beyotime Institute of Biotechnology. Elemental analyses were carried out with a Vario MICRO from Elementar Analysensysteme $\mathrm{GmbH}$, and the infrared spectra (IR) of $\mathrm{KBr}$ pellets were recorded in the range of $4000-400 \mathrm{~cm}-1$ on a SHIMADZU Prestige-21 spectrometer. Single crystal diffraction data were collected at $295 \mathrm{~K}$ on an Agilent Xcalibur Eos diffractometer with graphite monochromatized Mo-K $\alpha(\lambda=0.71073 \AA)$ radiation in $\omega$ scan mode. Powder X-ray diffraction (PXRD) patterns were collected at $293 \mathrm{~K}$ on a Bruker D8 diffractometer $(\mathrm{Cu} \mathrm{K} \alpha, \lambda=1.54059 \AA)$. The TG analyses were carried out on a Perkin Elmer TG/DTA 6300 thermal analyzer under flowing air atmosphere, with a heating rate of $10^{\circ} \mathrm{C} \mathrm{min}{ }^{-1}$. Luminescence spectra were measured on a Perkin Elmer LS 55 luminescence spectrometer. Solubility and oil-water Partition-coefficient (P) were determined on a SHIMADZU UV-2550 Ultraviolet visible spectrophotometer. The absorbance of MTT was measured on the BioTek ELX 500 microplate reader. The apoptosis and cell cycle were measured by FACS Calibur flow cytometry. Phatmacokenetics parameters were determinated by a Waters acquity ultra performance liquid chromatography (UPLC) system with an electrospray ionization (ESI) and a triple quadruple tandem MS/MS detector (TQD) system.

\section{General solution method for the synthesis of 5-fluorouracil-nicotinamide (5-FU-NCM) co- crystal}

The 5-FU-NCM co-crystal was synthesized by adding 5-FU (3 mmol, $390 \mathrm{mg})$ and NCM (1 mmol, $122 \mathrm{mg})$ into a mixed distilled water and methanol solution ( $\mathrm{v}: \mathrm{v}=1: 9)$. The mixture was stirred at room temperature for $10 \mathrm{~min}$, and then filtered. Colorless crystals suitable for X-ray diffraction were isolated from the filtrate after seven days. Yield: $88 \%$ (based on N). Elemental analysis calcd (\%) for C18H17F3N8O8: C 40.72, H 3.20, N 21.12; found: C 40.76, H 3.13, N 21.15.

\section{Grinding method for the synthesis of 5-fluorouracil-nicotinamide (5-FU-NCM) co-crystal}

To further explore the assemble process of 5-FU-NCM co-crystal, a grinding method was employed with the same reactants. A certain amount of 5-FU and NCM in 3:1 ratio was well mixed and ground for ca. $30 \mathrm{~min}$ in an agate mortar with a few drops distilled water being added to the grinding mixture. After dried by standing in air, the PXRD pattern of the above-mentioned grinding mixture has been carried out at room temperature. The formation and purity of 5-FU-NCM co-crystal was confirmed by comparison of the experimental PXRD pattern with the reference powder diffractogram (calculated on the basis of single crystal data of the 5-FU-NCM co-crystal obtained by conventional solution crystallization, Figure S1), which was carried out by the Mercury program available free of charge via the Internet at http://www.ccdc.cam.ac.uk.

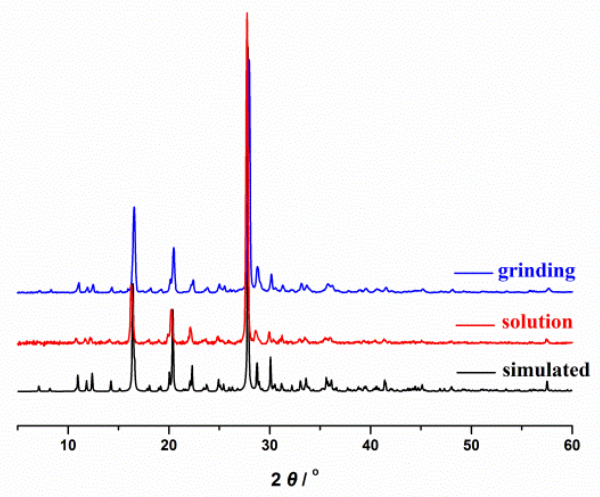

Figure S1. PXRD patterns of 5-FU-NCM co-crystal synthesized in different methods. 


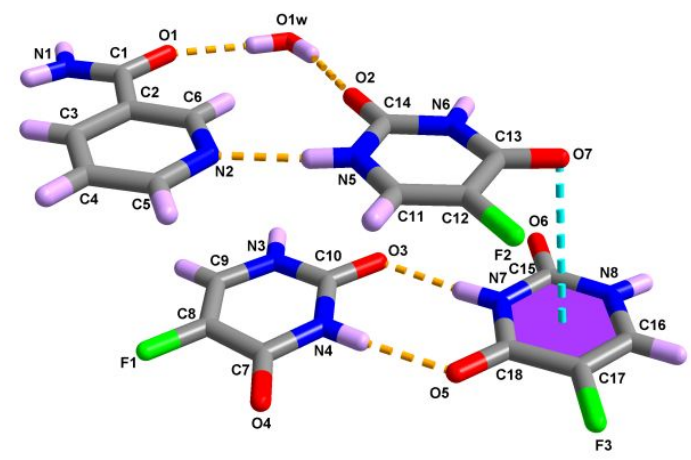

Figure S2. Molecule structure of 5-FU-NCM.

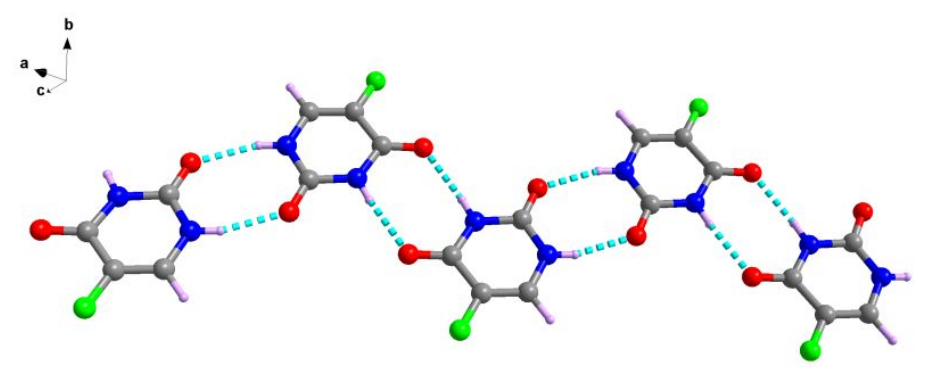

Figure S3. 5-FU hydrogen bond structure form.

\section{X-ray Crystallographic Measurements}

Table S1. Crystal data and structure refinement parameters of 5-FU-NCM co-crystal.

\begin{tabular}{|c|c|}
\hline Empirical formula & $\mathrm{C}_{18} \mathrm{H}_{17} \mathrm{~F}_{3} \mathrm{~N}_{8} \mathrm{O}_{8}$ \\
\hline Formula weight & 530.40 \\
\hline Crystal system & triclinic \\
\hline Space group & $P \overline{1}$ \\
\hline$a / \AA$ & $8.1842(8)$ \\
\hline$b / \AA$ & $11.5004(15)$ \\
\hline$c / \AA ̊$ & $12.7610(13)$ \\
\hline$\alpha / 0$ & $86.296(9)$ \\
\hline$\beta /{ }^{\circ}$ & $76.709(8)$ \\
\hline$\gamma /{ }^{\circ}$ & $69.343(10)$ \\
\hline$V I \AA^{3}$ & 1093.6(2) \\
\hline Z & 2 \\
\hline
\end{tabular}




\begin{tabular}{ll}
\hline$D_{\mathrm{c}} / \mathrm{g} \mathrm{cm}^{-3}$ & 1.611 \\
$\mu / \mathrm{mm}^{-1}$ & 0.144 \\
$F(000)$ & 544 \\
Reflections collected & 6492 \\
Unique reflections & 4980 \\
No. of parameter & 365 \\
R & 0.0144 \\
GOF on $F^{2}$ & 1.034 \\
Final R indices & $\mathrm{R} 1=0.0467 ; w R 2=0.1072$ \\
\hline
\end{tabular}

Table S1 provides a summary of the crystal data, data collection and refinement parameters for 5-FU-NCM co-crystal. The structure was solved by direct method and difference Fourier syntheses. All non-hydrogen atoms were refined by full-matrix least-squares techniques on F2 with anisotropic thermal parameters. The hydrogen atoms attached to carbons in these complexes were placed in calculated positions with $\mathrm{C}-\mathrm{H}=0.93 \AA$ (aromatic and ethylene $\mathrm{H}$ atoms), $\mathrm{C}-\mathrm{H}=0.97 \AA$ (methylene $\mathrm{H}$ atoms), and $\mathrm{U}(\mathrm{H})=1.2 \mathrm{Ueq}$ (C) in the riding model approximation. The hydrogen atoms attached to nitrogen atoms or water molecule were located in difference Fourier maps and were also refined in the riding model approximation, with $\mathrm{N}-\mathrm{H}$ and $\mathrm{O}-\mathrm{H}$ distance restraint $(0.86(1)$ or $0.85(1) \AA)$ and $\mathrm{U}(\mathrm{H})=1.5 \mathrm{Ueq}(\mathrm{N}, \mathrm{O})$. All calculations were carried out with the SHELXTL97 program. ${ }^{1}$ The CCDC reference number is 1494643 for 5-FU-NCM co-crystal. Selected hydrogen bond parameters for 5-FU-NCM is presented in Table S2.

Table S2. Hydrogen bond parameters for 5-FU-NCM co-crystal

\begin{tabular}{lllll}
\hline $\mathrm{D}-\mathrm{H} \ldots \mathrm{A}$ & \multicolumn{1}{c}{$\mathrm{d}(\mathrm{D}-\mathrm{H})$} & $\mathrm{d}(\mathrm{H} \ldots \mathrm{A})$ & $\mathrm{d}(\mathrm{D} \ldots \mathrm{A})$ & \multicolumn{1}{c}{$<(\mathrm{DHA})$} \\
\hline $\mathrm{N}(5) \mathrm{H}(5 \mathrm{~N}) \ldots \mathrm{N}(2)$ & $0.86(2)$ & $1.967(10)$ & $2.837(2)$ & $176(2)$ \\
$\mathrm{N}(1) \mathrm{H}(1 \mathrm{~N} 1) \ldots \mathrm{O}(1)^{\mathrm{i}}$ & $0.862(9)$ & $2.027(9)$ & $2.887(2)$ & $175.6(19)$ \\
$\mathrm{N}(4)-\mathrm{H}(4 \mathrm{~N}) \ldots \mathrm{O}(5)$ & $0.867(10)$ & $2.018(10)$ & $2.883(2)$ & $175(2)$ \\
$\mathrm{N}(1) \mathrm{H}(1 \mathrm{~N} 2) \ldots \mathrm{O}(7)^{\mathrm{ii}}$ & $0.849(9)$ & $2.030(10)$ & $2.875(2)$ & $174(2)$ \\
$\mathrm{N}(3)-\mathrm{H}(3 \mathrm{~N}) \ldots \mathrm{O}(3)^{\mathrm{iii}}$ & $0.856(9)$ & $1.950(10)$ & $2.803(2)$ & $174(2)$ \\
$\mathrm{N}(6) \mathrm{H}(6 \mathrm{~N}) \ldots \mathrm{O}(1 \mathrm{~W})^{\mathrm{iv}}$ & $0.863(10)$ & $1.952(10)$ & $2.813(2)$ & $175(2)$ \\
$\mathrm{N}(8)-\mathrm{H}(8 \mathrm{~N}) \ldots \mathrm{O}(6)^{\mathrm{v}}$ & $0.92(2)$ & $1.90(2)$ & $2.810(2)$ & $172(2)$ \\
$\mathrm{O}(1 \mathrm{~W}) \mathrm{H}(1 \mathrm{~W} 1) \ldots \mathrm{O}(1)$ & $0.861(9)$ & $1.950(9)$ & $2.810(2)$ & $176.9(19)$ \\
$\mathrm{O}(1 \mathrm{~W}) \mathrm{H}(1 \mathrm{~W} 2) \ldots \mathrm{O}(2)$ & $0.859(9)$ & $2.005(11)$ & $2.856(2)$ & $170.2(19)$ \\
$\mathrm{N}(7)-\mathrm{H}(7 \mathrm{~N}) \ldots \mathrm{O}(3)$ & $0.882(9)$ & $1.915(10)$ & $2.793(2)$ & $174(2)$ \\
\hline
\end{tabular}

Symmetry transformations used to generate equivalent atoms: (i) $-x+2,-y,-z$; (ii) $x, y, z-1$;

(iii) $-\mathrm{x}+1,-\mathrm{y},-\mathrm{z}+1$; (iv) $-\mathrm{x}+2,-\mathrm{y},-\mathrm{z}+1$; (v) $-\mathrm{x}+1,-\mathrm{y},-\mathrm{z}+2$

\section{IR spectroscopy}

As shown in Figure S4, the peaks 3539, 3469, $3360 \mathrm{~cm}^{-1}$ and at the range of 3167 2828 $\mathrm{cm}^{-1}$ in the 5-FU-NCM co-crystal can be assigned to the $v(\mathrm{~N}-\mathrm{H})$ stretching vibration, $\mathrm{v}(\mathrm{O}-\mathrm{H})$ absorption of the hydrogen bonds or water molecules. The strong absorption vibrations of the $\mathrm{C}=\mathrm{O}$ group are observed at 1718 and $1677 \mathrm{~cm}^{-1}$. The band appearing at the $1250 \mathrm{~cm}^{-1}$ is ascribed to the $v(\mathrm{C}-\mathrm{F})$ stretching vibration. This is consistent with the results of structural analysis. 


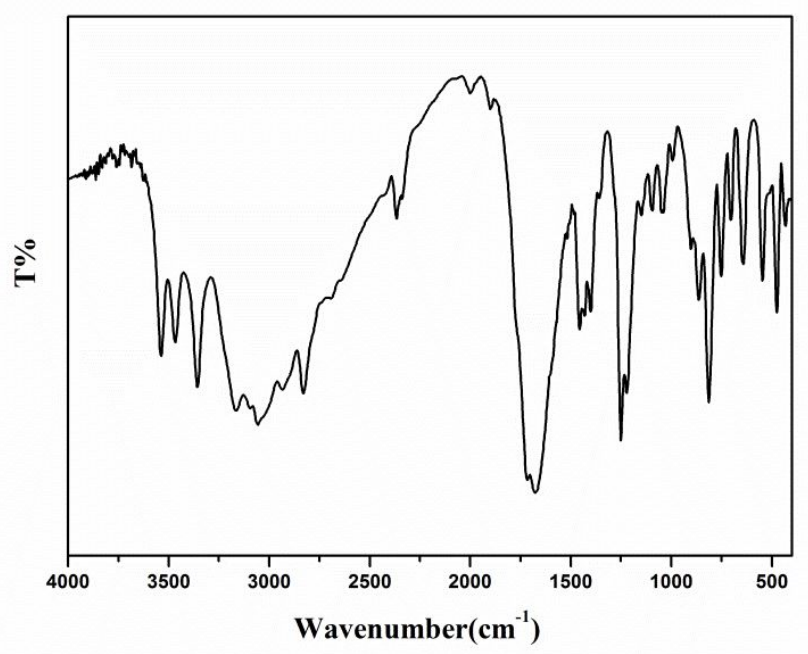

Figure S4. IR spectra of 5-FU-NCM co-crystal.

\section{TG analysis}

To examine the thermal behavior of the 5-FU, NCM and 5-FU-NCM co-crystal, in this study, their stabilities were analyzed on crystalline samples by thermogravimetric analyses (TG) from room temperature to $600{ }^{\circ} \mathrm{C}$ at a rate of $10{ }^{\circ} \mathrm{C}$ min ${ }^{-1}$, under $\mathrm{N} 2$ atmosphere. As shown in Figure S5, the TG curves indicate that the first weight loss occur in the range $215-260{ }^{\circ} \mathrm{C}$ for 5 -FU, 120$130{ }^{\circ} \mathrm{C}$ for $\mathrm{NCM}, 92-120^{\circ} \mathrm{C}$ for 5 -FU-NCM co-crystal, respectively. Upon subsequent heating, the total weight loss occurs at 583 ${ }^{\circ} \mathrm{C}$ for 5 -FU, $238^{\circ} \mathrm{C}$ for $\mathrm{NCM}, 470{ }^{\circ} \mathrm{C}$ for 5 -FU-NCM co-crystal, respectively. It is noted that there are two obvious weight-loss steps in the TG curve of the 5-FU-NCM co-crystal. Its first weight loss $(3.62 \%)$ between $92-123{ }^{\circ} \mathrm{C}$ is attributed to one free water molecule (cald 3.39\%).

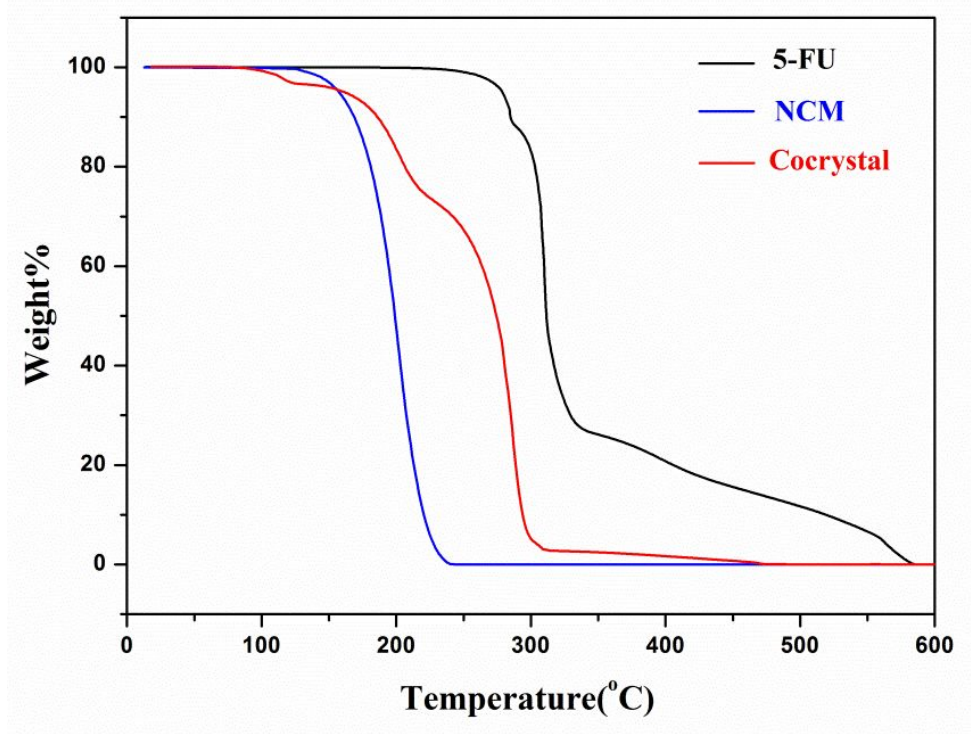

Figure S5. TG curves of 5-FU, NCM, 5-FU-NCM.

\section{Luminescent Properties}

The luminescent properties of 5-FU, NCM and 5-FU-NCM co-crystal in the solid state at room temperature were investigated. As shown in Figure S6, the emission spectra of 5-FU and NCM display emission maxima at 339 and $382 \mathrm{~nm}$ upon excitation at 300 and $338 \mathrm{~nm}$, which could be attributed to the $\pi-\pi^{*}$ transitions. ${ }^{2}$ In contrast to the emission of NCM, 5-FU-NCM co-crystal exhibits similar shape and maximum at $382 \mathrm{~nm}$ upon the same excitation. The same emission bands of 5-FU-NCM co-crystal is probably assigned to the NCM $\pi-\pi^{*}$ transitions. Meanwhile, the emission intensity of 5-FU-NCM co-crystal is smaller than that of NCM. The decreasing intensity of the 5-FU-NCM co-crystal is probably attributable to the formation of various non-covalent interactions, which reduce the rigidity of the NCM, thus increasing the loss of energy. 


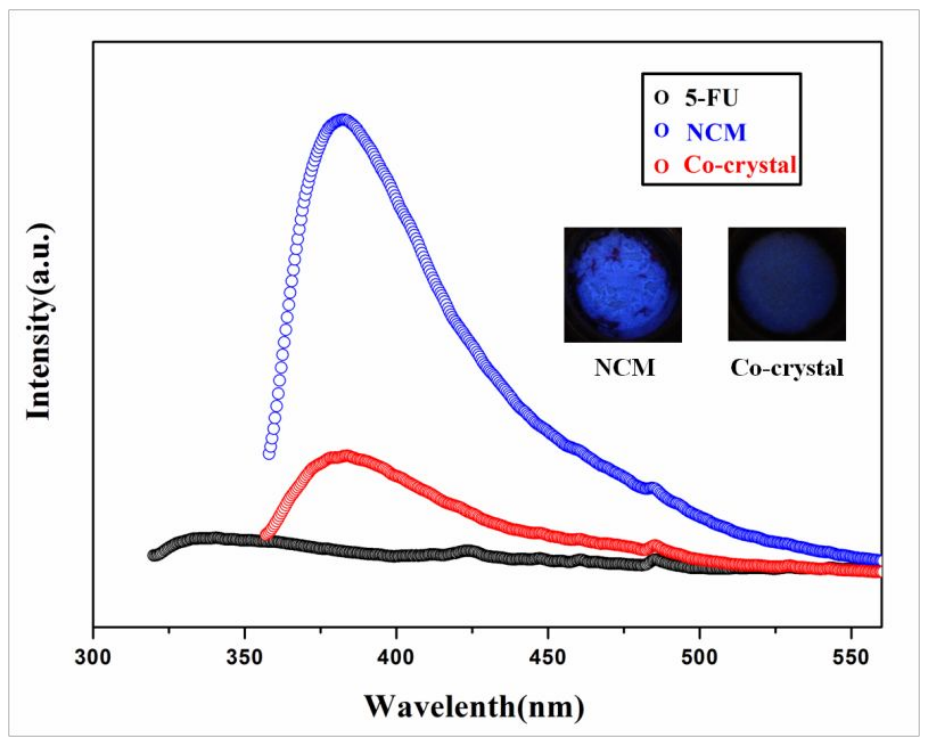

Figure S6. Emission spectra of 5-FU, NCM, 5-FU-NCM in solid-state at the room temperature

\section{Determination of solubility and oil - water partition coefficient}

Solubility and oil-water partition coefficient of 5-FU and 5-FU-NCM were measured by ultraviolet-visible spectrophotometry. The maximum absorbance wavelength of 5-FU and 5-FU-NCM aqueous solution were located at $265 \mathrm{~nm}$ and $263 \mathrm{~nm}$ respectively. 5-FU and 5-FU-NCM standard curve were measured at 293K (Table S3, S4, Figure S7, S8). The saturated aqueous solution 5-FU and 5FU-NCM were agitated respectively in capped conical flasks for $24 \mathrm{~h}$ at $293 \mathrm{~K}$. After filtrated, the diluted filtrated solution of 5-FU and 5-FU-NCM were measured at $293 \mathrm{~K}$ and calculated their solubility.

To explore the nature of the 5-FU and 5-FU-NCM in vivo, oil-water partition coefficient was measured in n-octanol/water system by shaking flask method at $293 \mathrm{~K}$. Briefly, the saturated aqueous solution 5-FU and 5-FU-NCM (50mL) and n-octanol(50mL) were mixed respectively well in a capped conical flask and then placed in an incubator shaker for $24 \mathrm{~h}$. After equilibration, the aqueous phase solution was measured and calculated their oil-water partition coefficient.

The partition-coefficient $(\mathrm{P})$ is the ratio of concentrations of a compound in mixture of two immiscible phases at equilibrium. The value of $\log \mathrm{P}$, a measure of lipophilicity or hydrophobicity, indicates the solubility of the compound in water or oil. The smaller the number, the more hydrophilic the compound is. Our result showed the $\log \mathrm{P}$ value of co-crystal is $-1.17(\mathrm{P}=0.068)$, while the log $\mathrm{P}$ of 5-FU is $-0.46(\mathrm{P}=0.35)$. This suggests that the co-crystal molecule is more hydrophilic and has lower membrane permeability compared to its API. The low permeability of 5-FU-NCM could potentially limit its transport through lipophilic cell and organellar membranes, thus diminishing its bioavailability.

Table S3. 5-FU Standard Curve

\begin{tabular}{llllllll}
\hline Conc. (mmol/L) & 0 & 0.01000 & 0.02000 & 0.04000 & 0.06000 & 0.08000 & 0.10000 \\
\hline Absorbance & 0.00013 & 0.06733 & 0.13612 & 0.28028 & 0.39245 & 0.54537 & 0.67691 \\
\hline
\end{tabular}

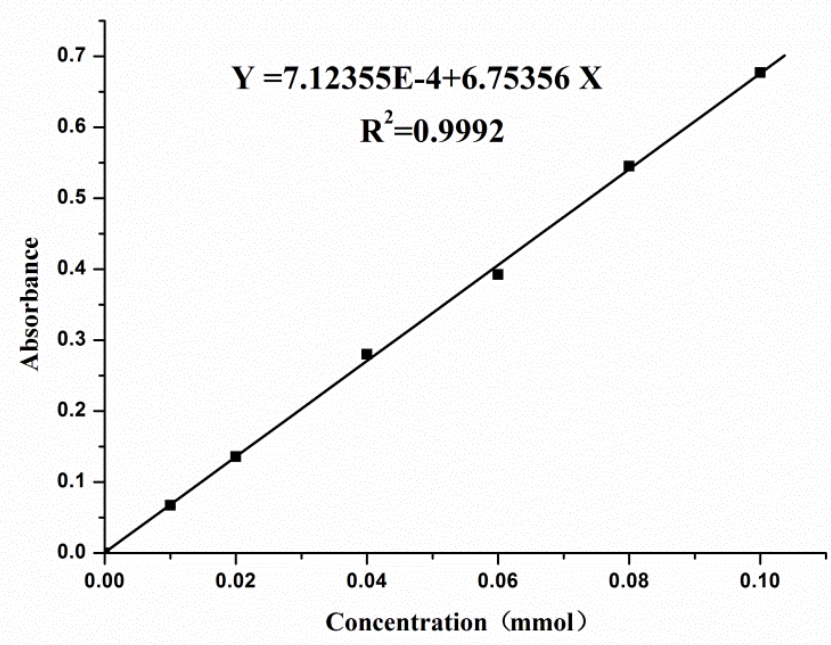

Figure S7. 5-FU standard Curve

Table S4. 5-FU-NCM Standard Curve

\begin{tabular}{llllllll}
\hline Conc. $(\mathrm{mmol} / \mathrm{L})$ & 0 & 0.00400 & 0.00800 & 0.01600 & 0.02400 & 0.02800 & 0.04000 \\
\hline Absorbance & 0.00055 & 0.09234 & 0.20147 & 0.37760 & 0.56305 & 0.62820 & 0.91931 \\
\hline
\end{tabular}




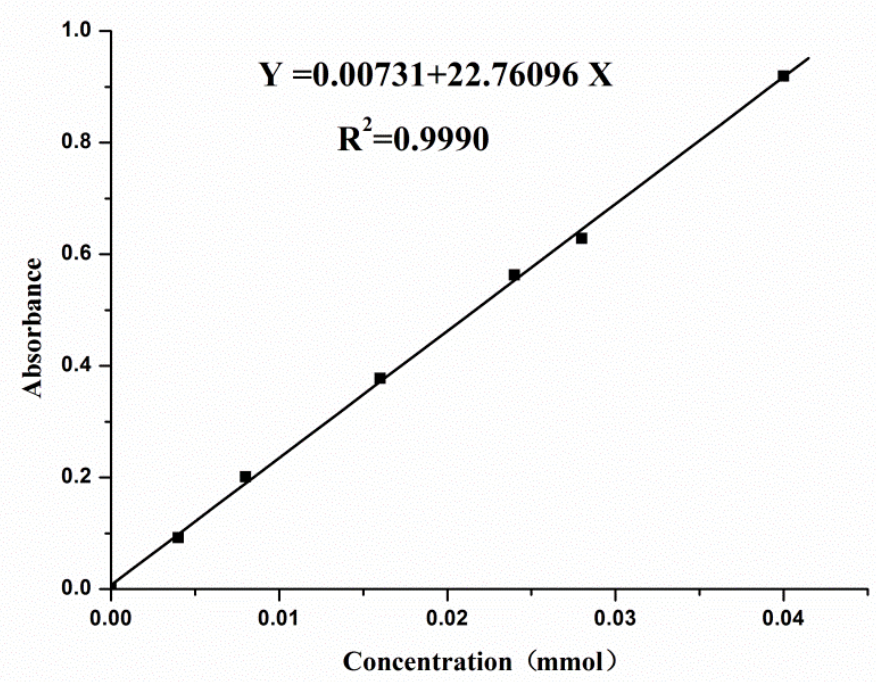

Figure S8 5-FU-NCM Standard Curve

\section{Cell inhibitory assay}

We carried out 3-(4,5-dimethylthiazol-2-yl)-2,5-diphenyltetrazolium bromide (MTT) assay on the human colorectal cancer cell line HCT116, human choriocarcinoma cell line JEG3, human hepatocellular carcinoma cell line SMMC7721, human hepatoma cell line HepG2 and human cervical cancer cell line HeLa. The tumour cells were seeded in a 96-well plate in a final volume of $200 \mu \mathrm{L} / \mathrm{well}$ of culture medium, at $1 \times 10^{4}$ cells/well $24 \mathrm{~h}$ prior to treatment. The cells were treated with 5 -FU alone and the 5-FU-NCM co-crystal in the concentration range between $10-8$ and $10^{-3} \mathrm{~mol} / \mathrm{L}$ with the interval of $10^{-1} \mathrm{~mol} / \mathrm{L}$. After 24,48 , and $72 \mathrm{~h}$ of drug exposure, 20 $\mu \mathrm{L}$ of $5 \mathrm{mg} / \mathrm{mL}$ MTT was added to each well. After $4 \mathrm{~h}$ incubation at $37^{\circ} \mathrm{C}, 150 \mu \mathrm{L}$ DMSO was added and rocked at room temperature for $15 \mathrm{~min}$. The absorbance was measured at $490 \mathrm{~nm}$. Cells treated with 5-FU was used as the controls for the cells treated with 5FU-NCM(Figure S9).
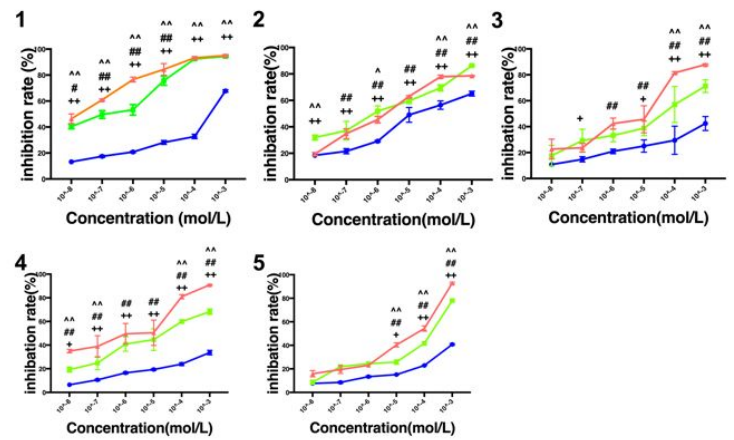

Figure S9. Co-crystal inhibitory rate on different cells (1-5) Effective suppression of the human colorectal cancer cell line HCT116, human cervical cancer cell line HeLa, human hepatoma cell line HepG2, human choriocarcinoma cell line JEG3 and human hepatocellular carcinoma cell line SMMC7721, and by exposure of 5FU-NCM at a series of concentrations from $10^{-8}$ to $10^{-3} \mathrm{~mol} / \mathrm{L}$ with the interval of an order of magnitude, and the time $24,48,72 \mathrm{~h}$ apartly. ${ }^{-} \mathrm{x} \pm \mathrm{SD}, \mathrm{n}=3,{ }^{* *} \mathrm{p}$ $<0.01,{ }^{*} p<0.05$, one-way ANOVA.

\section{Determination of cell cycle Determination of cell cycle}

We exposed HCT116 cells to $5 \mu \mathrm{M}$ of 5-FU-NCM and 5-FU for $12 \mathrm{~h}$. Cells fixed with $70 \%$ ethanol, and then stored at $20{ }^{\circ} \mathrm{C}$ for at least $24 \mathrm{~h}$. Next, the cells were washed with phosphate buffered saline (PBS), incubated with $10 \mu \mathrm{g} / \mathrm{mL}$ RNase A at $37^{\circ} \mathrm{C}$ for 20 $\mathrm{min}$, and then stained with $20 \mu \mathrm{g} / \mathrm{mL}$ propidium iodide. DNA contents of the cells (10,000 cells/group) were quantified by flow cytometry.

\section{Assessment of Apoptosis by Annexin V-FITC/PI Staining}

HCT116 cells apoptosis analyses were carried out by flow cytometry. HCT116 cells were treated with the concentrations of 5-FUNCM $5 \mu \mathrm{M}$ for 12 and $24 \mathrm{~h}$. After the treatment, the cells were harvested by $0.25 \%$ trypsin and washed by phosphate-buffered saline (PBS) and then resuspended in $200 \mu \mathrm{L}$ binding buffer with an addition of $5 \mu \mathrm{L}$ Annexin $\mathrm{V}$-fluorescein isothiocyanate and $10 \mu \mathrm{L}$ propidium iodide. The mixture was kept in the dark for $15 \mathrm{~min}$ at $4{ }^{\circ} \mathrm{C}$ and then $300 \mu \mathrm{L}$ of binding buffer was added and analyzed immediately with flow cytometry.

\section{In vivo anti-tumor activity}

The HCT116 cells were distributed in normal saline and counted under the microscope. To build the xenograft tumor model in mic $\mathrm{BALB} / \mathrm{c}$ nude mice, the procedure was performed by subcutaneous inoculation of $0.1 \mathrm{~mL}$ containing $5 \times 10^{5}$ viable tumor cells into 
the right flank of each mouse of the mice. After 3 days, mice were randomly divided by six groups, and received daily injections in left hypogastrium for 21 days as following: three groups received $0.006,0.012,0.018 \mathrm{mmol} / \mathrm{kg} / \mathrm{d}$ of 5-FU-NCM, respectively; one group was treated with mixture $(0.036 \mathrm{mmol} / \mathrm{kg} / \mathrm{d} 5-\mathrm{FU}$ plus $0.012 \mathrm{mmol} / \mathrm{kg} / \mathrm{d} \mathrm{NCM})$; one group received $5-\mathrm{FU}$ alone $(0.036$ $\mathrm{mmol} / \mathrm{kg} / \mathrm{d}$ ); and the final group was as the blank group.

\section{Pharmacokinetics in vivo}

Sixteen Sprague-Dawley rats were randomly divided into two groups: one group received 5-FU only while the other one received 5FU-NCM co-crystal. Blood was collected at some serial intervals such as 1, 5, 10, 15, 20, 30, 60, 90 and 120 min after administration. Samples were analyzed by UPLC-MS / MS after pretreated.

\section{References}

[1] Sheldrick G. M. SHELXTL-97, Program for Crystal Structure Refinement. University of Göttingen. 1993.

[2] Burns D. T. Fluorescence and phosphorescence - analytical chemistry by open learning (ACOL). Analytica Chimica Acta. 1988, 212, 364365. 